\title{
Japanese Studies
}

\section{Японоведение}

DOI 10.31696/2618-7043-2020-3-2-379-400

Переводы

УДК 94(520)»1572/1573»(093.3)

Translation

\section{О:та Гю:ити. "Записи о князе Нобунага". Свиток VII}

\author{
С. А. Полхов \\ (Перевод с позднесредневекового японского, комментарии и предисловие) \\ Институт востоковедения РАН, г. Москва, Российская Федерация \\ ORCID: https://orcid.org/0000-0003-4705-7488, e-mail: cjr-ran@yandex.ru
}

Резюме: в данной публикации представлен комментированный перевод на русский язык свитка VII хроники «Синтё:-ко: ки» («Записи о князе Нобунага»). Свиток VII повествует о войне домов Ода и Токугава с даймё Такэда Кацуёри, а также о том, как Ода Нобунага получил часть благовонного дерева Рандзятай из императорской сокровищницы в монастыре То:дайдзи. Кроме того, свиток содержит подробное описание военного похода Нобунага против Нагасима Икко:-икки.

Ключевые слова: Синтё:-ко: ки, Ода Нобунага, Сэнгоку дзидай, Такэда Кацуёри, Токугава Иэясу, Икко:-икки

Амя цитирования: О:та Гю:ити. «Записи о князе Нобунага». Свиток VII (Перевод с позднесредневекового японского, комментарии и предисловие С. А. Полхова). Ориенталистика. 2020;3(2)379-400. DOI: 10.31696/2618-7043-2020-3-2-379-400.

\section{Ōta Gyūichi. "Shinchō-kō ki”. Book VII}

\section{S. A. Polkhov}

(Translation into Russian from late medieval Japanese, comments and introduction) Institute of Oriental Studies of the Russian Academy of Sciences, Moscow, Russian Federation ORCID: https://orcid.org/0000-0003-4705-7488, e-mail: cjr-ran@yandex.ru

Abstract: the publication provides a commented translation into Russian of the book VII of Shinchō-kō ki chronicle. The book VII narrates about war between Oda, Tokugawa houses and daimyō Takeda Katsuyori and about Oda Nobunaga acquiring the piece of the fragrant tree Ranjatai from imperial treasury in Tōdaiji monastery. The book also contains the description of Nobunaga military campaign against Nagashima Ikkō-ikki. The article continues the series of translations of books of Shinchō-kō ki, previously published by the author.

Keywords: Shinchō-kō ki, Oda Nobunaga, Sengoku Jidai, Takeda Katsuyori, Tokugawa Ieyasu, Nagashima, Ikkō-ikki

For citation: Ōta Gyūichi. "Shinchō-kō ki". Book VII (Translation into Russian from late medieval Japanese, comments and introduction S. A. Polkhov). Orientalistica. 2020;3(2):379-400. (In Russ.). DOI: 10.31696/2618-7043-2020-3-2-379-400.

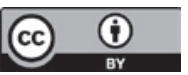

Контент доступен под лицензией Creative Commons Attribution 4.0 License. This work is licensed under a Creative Commons Attribution 4.0 License.

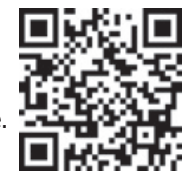




\section{Свиток VII хроники "Синтё:-ко: ки" ("Записи о князе Нобунага")', 2-й год [Аевиза правления] Тэнсё:, собаки и старшего брата дерева ${ }^{2}$}

Сложил это 0:та Идзуми-но ками

1. О том, как головы троих - Асакура Ёсикагэ, Адзаи Симоцукэ, Адзаи Бидзэн [подали] на закуску.

2. О гибели Маэба [и о том], как осиным роем поднялись [силы] икки в Этидзэн.

3. О мятеже Иибасама в замке Акэти.

40 том, как [его милость] повелел отрезать [часть древа] Рандзятай.

5. О том, как Сасаки Дзё:тэй отступил из замка Исибэ.

6. О том, как [князь Нобунага] выбрал коней для лошадиных скачек в Камо.

7. О мятеже Огасавара Ёхатиро: из замка Такатэндзин.

8. О том, как [его милость] одарил князя Иэясу золотом.

9. О том как [его милость] покорил всю [область] Каваути Нагасима.

10. Об умерщвлении мужа и жены Хигути.

11. 0 том, как [его милость] велел приобрести знаменитые вещи ${ }^{3}$.

(1). Первая луна, первый день. Все ${ }^{4}$ из Киото и соседних земель, находились в Гифу, предстали [перед князем Нобунага]. Для всех [гостей был устроен] званый пир с [церемонией] сангон 5 . После того как удалились вассалы из других земель, [и остались] лишь оумамавари, вынесли диковинную закуску, о которой не доводилось слышать ни в нынешние, ни в прошлые времена, и снова пошел пир.

Добытые в прошлом году [князем Нобунага] в северных землях [головы]:

голова Асакура Сакё:-но дайбу Ёсикагэ,

1 За основу взят опубликованный список «Записей о князе Нобунага» из книгохранилища Ё:мэй [1]. Данная работа является продолжением серии академических переводов «Записей о князе Нобунага», ранее опубликованных автором. Перевод свитков I-VI см.: [2-5]. Ранее написанный мной обзор японских исследований, посвященных этому источнику см.: [6].

2 2-й год Тэнсё: - по европейскому летоисчислению промежуток времени с 23.01.1574 по 10.02.1575.

${ }^{3}$ В начале свитка дано лишь название 11-го раздела, однако сам текст его отсутствует.

${ }^{4}$ Все из Киото и соседних земель (Кё:то рингоку-но мэнмэн 京都隣国面々) - видные военачальники из Киото и соседних земель. Они же - «вассалы из других земель» такокусю (他国衆), подчинившиеся Нобунага после его похода на Киото в 1568 г. В «Записях о Нобунага» (список дома Икэда) вместо Кё:то рингоку-но мэнмэн читаем Гокинай рингоку-но даймё: сё:мё: (五畿内隣国之大名小名), «большие и малые владетели пяти столичных [провинций] и соседних земель». - См.: Синтё:ки. Икэда-кэ бунко бон. Дайнихон сирё:, ч. 10, т. 20, с. 427 (на япон. яз.) на сайте: www.hi.u-tokyo.ac.jp.

5 Японский пиршественный обычай, предусматривавший троекратное поднесение гостям столиков с тремя чарками сакэ и закусками. 


\section{голова Адзаи Симоцукэ,} голова Адзаи Бидзэн.

Всего три позолоченные ${ }^{6}$ [головы] положили на [столики] кугё: и подали на закуску, пиршество [продолжилось]. [Все] нараспев читали [отрывки из пьес] ${ }^{8}$ и предавались веселью. Всё, [решительно] всё [шло] замечательно - согласно замыслам [его милости], [и князь Нобунага] радовался.

(2). Первая луна, 19-й день. Дошла весть о том, что Маэба Харима из Этидзэн предали смерти самураи [этой] земли. Причина [такова]: [князь Нобунага] назначил его заместителем сюго большой земли, но [Маэба] возгордившись преуспеванием и могуществом, вел себя своевольно во всех делах, вынося решения, был до крайности не учтив к сотоварищам. Потому все самураи [Этидзэн] подняли мятеж, предали [его] смерти ${ }^{9}$ и после того на окраинах земли, на границе, возвели крепости, разместив там гарнизоны. После этого [дошли] вести, что землей Этидзэн завладели [силы] икки ${ }^{10}$. [Князь Нобунага] изволил послать войско в Цуруга Хасиба Тикудзэн-но ками, Муто: Со:эмон, Нива Горо:дзаэмон, Фува Кавати-но ками, Фува Хикодзо:, Марумо Хё:го, [Марумо] Сабуро:бё:э, людей провинции Вакаса.

${ }^{6}$ Позолоченные - хакутами ни ситэ (薄濃にして): головы покрыли лаком, после чего расписали тонким слоем золотой краски. См. примечания [1, с. 165].

7 Кугё: (公卿) - низкие прямоугольные столики на подставке, делавшиеся из некрашеного кипарисовика, разновидность обеденных столиков цуйгасанэ (衝重).

8 Нараспев читали [отрывки из пьес] - гоутаи (御謡). Утаи (謡) - декламирование текстов пьес театра Но и фарсов Кёгэн [7]. Утау (謡う) - «слагать стихи», «петь песни».

9 Маэба Харима - Маэба Ёсицугу (?-1574), бывший вассал Асакура Ёсикагэ, согласно «Записям» назначенный Нобунага на пост заместителя военного наместника (сюгодай), а согласно военной повести «Асакура симацуки» (朝倉始末記 примерно 1577 г.), и хронике «То:дайки» (当代記, период Токугава) - на пост военного наместника (сюго) провинции Этидзэн [8, с. 401; 9, с. 19]. Получил от Нобунага новую фамилию - Кацурада, а также право распоряжения конфискованными землями Асакура Ёсикагэ и его вассалов, не подчинившихся Нобунага [8, с. 402]. Согласно «Асакура симацуки» соперником Маэба Ёсицугу, желавшим получить пост сюго Этидзэн или же половину этой земли, был Тода Нагасигэ (1551-1574), другой бывший вассал дома Асакура, также ранее перешедший на сторону Нобунага. Нагасигэ стал вдохновителем восстания самураев Этидзэн, недовольных Ёсицугу, который был атакован восставшими и убит в 19-й день первой луны 2-го года Тэнсё: $(1574)$ [8, с. 403, 404].

10 Силы Икко:-икки - силы последователей «Истинной школы Чистой земли» (Икко:-сю), руководимых из Одзака (часть территории совр. г. Осака). Устранив Маэба Ёсицугу, Тода Нагасигэ, возможно, не намеревался бунтовать против Нобунага и рассчитывал на признание своего преобладания в Этидзэн с его стороны. - См.: Фукуи кэн си. Цу:си хэн 3. Кинсэй 1. 1994. (на япон. яз.) на сайте www.library-archives.pref.fukui.lg.jp. Однако в борьбу за власть в этой провинции вмешался Кэннё, верховный настоятель храма Хонгандзи из Одзака, направивший туда своего эмиссара Ситири Райсю:. Последний, возглавив многочисленных последователей «Истинной школы Чистой земли» в Этидзэн, а также отряды из примкнувших к ним самураев, напал на Тода Нагасигэ. После гибели Нагасигэ уезды Этидзэн перешли под управление ставленников Хонгандзи [10, с. 136]. 
(3). Первая луна, 27-й день. Поступили донесения, что Такэда Сиро: Кацуёри ${ }^{11}$ двинулся к Ивамура и окружил замок Акэти. Немедленно, чтобы напасть с тыла [на врага] ${ }^{12}$ в первый день 2-й луны, [князь Нобунага] послал передовые силы - войско двух земель, провинции Овари и провинции Мино.

2-я луна, 5-й день. Нобунага вместе с сыном направили коней [к замку Акэти], в тот день встали лагерем в Митакэ. На другой день расположили свою ставку в Ко:но. На следующий день [князь Нобунага] собирался устремиться на [врага], но в горах, в труднопроходимой и обрывистой местности [противники] не могли атаковатьдруг друга ${ }^{13}$.Переместившись в горы, [князь Нобунага] уже готов был приказать двинуть войско, как в замке поднял мятеж Иибасама Уэмон ${ }^{14},[0 н]$ пал, и ничего нельзя было сделать ${ }^{15}$. Приказав укрепить замок Ко:но, [князь Нобунага] изволил оставить его комендантом Кавадзири Ёхё:э. Кроме того, [он] укрепил замок Ори, соизволив оставить [во главе] гарнизона Икэда Сё:дзабуро:.

2-я луна, 24-й день. Нобунага с сыном вернулись в замок Гифу.

3-я луна, 12-й день. Нобунага отбыл в Киото. Остановился [на] дватри дня в Саваяма. В 16-й день остановился [на ночлег] в Нагахара. В 17-й день соблаговолил переправиться из Сина в Сакамото по озеру [Бива].

11 Такэда Кацуёри (1546-1582), сын и преемник даймё Такэда Сингэн (1521-1573). В конце 1572 г. Сингэн начал войну против домов Токугава и Ода, в которой добился значительных успехов. Под его контроль перешли значительные территории в провинциях То:то:ми и Суруга, а также ряд крепостей на востоке провинции Мино.

12 Чтобы напасть с тыла [на врага] - усиродзумэ тоситэ (後詰として). Возможный вариант перевода - «на подмогу». Усиродзумэ (後詰) - это 1) запасной (резервный) отряд позади основных сил, готовый в случае необходимости прийти им на помощь; 2) нападение с тыла на врага; войско, нападающее с тыла на врага (синонимы усиродзэмэ 後攻, усиромаки 後巻) [7].

${ }^{13}$ Не могли атаковать друг друга - тагаи ни какэаи нарадзу со:ро: (互に懸合ならず候), дословно «сражение между двумя сторонами не было возможно». В английском переводе: "The steep and rugged terrain prevented any cavalry engagements between two armies" [11, p. 205]. Слово какэаи (䀣合) действительно означает «сражение кавалерийских отрядов, всадников». Однако какэаи также переводится как «нападение и вступление в битву двух армий». - См.: Нихон кокуго дайдзитэн. 2-е изд. Сёгакукан, 2001 (на япон. яз.) на сайте www.kotobank.co.jp). Такой вариант перевода предпочтительнее. Подразумевается, что обеим сторонам было затруднительно развернуть свои силы и провести битву.

${ }^{14}$ Иибасама Уэмон-но дзё: (?-1582). Отпрыск рода Иибасама, ветви То:яма, разветвленного самурайского дома в восточной части провинции Мино. Как и другие линии этого дома (Ивамура, Наэки), Иибасама долгое время признавали власть и даймё Ода, и даймё Такэда [12, с. 77].

15 В свете информации «Записей о князе Нобунага» представляется недостоверным сообщение нарративного источника «Военное зерцало провинции Каи» («Ко:ё: гункан» 甲陽軍鑑, начало XVII в.) о том, что воины Такэда загнали Иибасама Уэмон-но дзё: на склад (кура 蔵) главной цитадели замка и взяли в плен [13, св. 19, с. 105]. 
(4). [Князь Нобунага] впервые поселился в [храме] Сё:кокудзи ${ }^{16}$. [Он почтительно] доложил государю ${ }^{17}$ о своем желании [касательно благоухающего древа] Рандзятай из [храма] То:дайдзи ${ }^{18}$ в Южной столице ${ }^{19}$.

3-я луна, 26-й день. Государевы посланцы, господин Хино Тэрусукэ и господин старший советник Асукаи ${ }^{20}$, [сообщили о] повелении его величества в милостиво составленном высочайшем указе ${ }^{21}$, и монахи

${ }^{16}$ Сё:кокудзи (相国寺) - храм школы Риндзай, с 1386 г. второй по рангу из пяти главных дзэнских монастырей Японии эпохи Муромати (согласно системе годзан 五山). Строительство храмового комплекса было начато Асикага Ёсимицу (1358-1408) в 1382 г. Важный культурный центр, пользовавшийся особым покровительством сёгунов династии Асикага, которые регулярно посещали Сё:кокудзи [7].

17 Государю - дайри (内裏). Дайри - палаты в императорском дворцовом комплексе, где пребывал государь. Вместе с тем этим словом именовали и самого императора. - См.: Нихон кокуго дайдзитэн. 2-е изд. Сёгакукан, 2001 (на япон. яз.) на сайте www.kotobank. co.jp. В «Записях о Нобунага» (список дома Икэда) вместо дайри встречаем бином тэйо: (帝王), что значит «государь», «император». - См.: Синтё:ки. Икэда-кэ бунко бон. Дайнихон сирё:, ч. 10, т. 21, с. 266 (на япон. яз.) на сайте www.hi.u-tokyo.ac.jp.

18 То:дайдзи - крупнейший храмовый комплекс г. Нара, основанный в 745 г. императором Сё:му (701-756). Главный храм школы Кэгон и важнейший религиозный центр. Известен Павильоном Великого Будды (Дайбуцу дэн), где находится колоссальная бронзовая статуя Великого Будды (Дайбуцу, Будда Вайрочана). В Средние века располагал многочисленными вотчинами, но утратил контроль над многими из них во 2-й половине эпохи Муромати [7].

19 Рандзятай (蘭奢待) - древесина аквиларии (Aquilaria agalocha Roxb.), тропического дерева, ценившегося за ароматические свойства. Принято считать, что Рандзятай было привезено в Японию в правление императора Сё:му (701-756) из Китая. Элементами иероглифов Рандзятай являются три знака, образующие название монастыря То:дайдзи (東大寺), поэтому Рандзятай было еще одним названием этого храма [14, с. 131]. «Благоухающее древо» хранилось в императорской сокровищнице Сё:со:ин при храме То:дайдзи в Нара («Южной столице»). Отрезать его часть можно было только с дозволения императора. В 1465 г. такое разрешение получил сёгун Асикага Ёсимаса (1436-1490) во время посещения Нара.

${ }^{20}$ Хино Тэрусукэ (?-1623) - придворный аристократ, дослужившийся до 2-го старшего ранга и должности заместителя (помощника) старшего советника Палаты большого государственного совета (гон дайнагон). Асукаи Масанори (Масахару, 1520-1594), другой сановник императорского двора, отпрыск ветви рода Фудзивара. В 1574 г. удостоился старшего 2-го ранга, в 1575 г. - должности гон дайнагон [15, с. 43, 654]. 0:та Гю:ити ошибочно приписал ему должность старшего советника (дайнагон), которую Асукаи Масанори не занимал.

21 Высочайший указ - гоиндзэн (御院宣). Индзэн - указ, составлявшийся по воле отрекшегося государя (дзё:ко 上皇) его приближенными. На тот момент при императоре 0:гимати (1517-1593) не было отрекшегося государя. По всей видимости на самом деле был составлен риндзи (綸旨) - документ, излагающий волю императора, составленный его приближенными, или же нё:бо: хо:сё: (女房奉書) - послание с повелением императора, написанное азбукой кана придворными дамами. В период Сэнгокуэтот тип документации играл роль не менее важную, чем указы риндзи. Нё:бо: хо:сё: иногда писались самими государями. Подробнее о вышеуказанных видах документации см.: [16, с. 101-118]. 
Южной столицы почтительно приняв [его], повиновались ${ }^{22}$. На другой день - 27-й день 3-й луны - Нобунага соизволил прибыть в [замок] Тамон в Нара ${ }^{23}$.

Распорядители [его милости]: Бан Куро:дзаэмон, Сугая Куэмон, Сакума Уэмон, Сибата Сюри, Нива Горо:дзаэмон, Хатия Хё:го-но ками, Араки Сэтцу-но ками, Сэкиан, Ю:кан.

Главный распорядитель [его милости]: Цуда Бо:24.

3-я луна, 28-й день. В час дракона государева сокровищница ${ }^{25}$ открылась. Это знаменитое благоухающее [древо] помещено было в продолговатый сундук ${ }^{26}$ длиной 6 сяку ${ }^{27}$. Тотчас же [его] доставили

22 Как свидетельствуют записи из дневников «Дзинкэнки» и «Тамонъин никки» в 21-й день 3-й луны в Нара прибыл Бан Наомаса, высокопоставленный вассал Нобунага. - См.: Дзинкэнки; Тамонъин никки. Дайнихон сирё:, ч. 10, т. 21, с. 262, 264 (на япон. яз.) на сайте www.hi.u-tokyo.ac.jp. Он посетил храм То:дайдзи и уведомил о желании своего господина «взглянуть» на дерево Рандзятай. Вслед за этим стало известно, что Нобунага прибудет в Нара уже в 27-й день 3-й луны. - См.: Дзинкэнки. Дайнихон сирё:, ч. 10, т. 21, c. 264 (на япон. яз.) на сайте www.hi.u-tokyo.ac.jp. Согласно «Мицукура кайфу: никки» (三蔵開封日記), записям Дзё:дзицу, временного распорядителя (нэнъё госи) храма То:дайдзи, составленным в 1574 г., вскоре после описываемых событий, Бан Наомаса на встрече с ним сказал, что в случае согласия с просьбой Нобунага, последний поспособствует возвращению исконных земель То:дайдзи [17, с. 254]. На спешно созванном совете монашеской братии констатировали, что сокровищница Сё:со:ин открывалась лишь во время паломничества сёгуна (Асикага Ёсимаса) в святилище Касуга. Запрос Нобунага был признан беспрецедентным и противоречащим прежним установлениям (сэнки ни сомуки 背先規), а также чреватым позором для храма. Обсуждение затянулось до ночи, при этом к монахам неоднократно прибывали посланцы Цуцуи Дзюнкэй (1549-1584), одного из магнатов провинции Ямато и вассала Нобунага, требовавшие не затягивать с принятием решения. В конце концов совет постановил: хотя прежде двери Сё:со:ин и открывались лишь во время посещения сёгуна (Муромати доно), Нобунага не только восстановил обветшавший государев дворец, но и передал обширные земли во владения императора, покарал его врагов, а посему подобает ему взглянуть на благовонное древо. При этом монахи настаивали на соблюдении сложившихся церемониальных правил: сорвать старые и наложить новые печати на двери сокровищницы должен был посланник самого императора. Кроме того, они намеревались в экстренном порядке назначить настоятеля храма (бэтто:), пост которого был на тот момент вакантным $[17$, c. 254]. Таким образом, решение монахов было неохотным и вынужденным - они не припомнили похожих случаев и посчитали, что просьба Нобунага идет вразрез с устоявшимися правилами. С одной стороны, их торопили вассалы Нобунага, с другой - они, должно быть, боялись его прогневать.

${ }^{23}$ Нобунага прибыл в Нара в сопровождении внушительного военного отряда в 3 тыс. с лишним человек. - См.: Тамонъин никки. Дайнихон сирё:, ч. 10, т. 21, с. 262 (на япон. яз.) на сайте www.hi.u-tokyo.ac.jp.

${ }^{24}$ Ода Нобудзуми (1558-1582), сын Ода Нобукацу, младшего брата Нобунага. В «Мицукура кайфу: никки» он назван «представителем» (мё:дай 名代) Нобунага [17, с. 255].

${ }^{25}$ Государева сокровищница - окура (御蔵), дословно «государево хранилище».

26 Продолговатый сундук - нагамоти (長持), длинный прямоугольный сундук.

27 Сяку (尺) - мера длины в традиционной Японии, с 1891 г. 1 сяку приравнивался приблизительно к 33 см. 1 сяку = 10 сун. 
в [замок] Тамон ${ }^{28}$, [где] в покоях для высочайших визитов на помосте было представлено на высочайшее обозрение [князя Нобунага]. Следуя исконным правилами, [по воле князя Нобунага] отрезали [часть древа] длиной в 1 сун ${ }^{29}$ и 6 бу ${ }^{30}$. [Князь Нобунага] велел взглянуть [на древо] сопровождавшим [его] оумамавари, чтобы [было о чем] рассказывать в грядущие времена. [Сподобились они] узреть [это чудо] благодаря могуществу и величию, и благодаря милосердию [своего господина]. Память на [всю] жизнь - словами не описать, сколь благодарны [они] были [князю Нобунага]. С тех пор как в один год [часть древа] соблаговолил взять господин Хигасияма ${ }^{31}$, многие господа из дома сёгунов желали [того же], но поскольку непросто [было получить разрешение], ничего не добились. Благодаря покровительству Будд и небесных божеств ${ }^{32}$ [князь Нобунага] обрел сокровище ${ }^{33}$, знаме-

${ }^{28}$ В соответствии с прежними прецедентами на вакантный пост настоятеля (бэтто:) монастыря в спешном порядке был назначен малолетний сын влиятельного придворного сановника Сандзё:ниси Санэё (1511-1579). Именно бэтто: полагалось вручить государев указ, дозволяющий отворить Сё:соин, без него соблюдение должного церемониала не представлялось возможным.

${ }^{29}$ Сун (寸), десятая часть сяку, после 1891 г. 1 сун считался примерно равен 3,03 см. 1 сун $=10$ бу (分).

30 Нобунага пожелал, чтобы часть Рандзятай была отрезана в присутствии монахов То:дайдзи, чтобы не быть обвиненным в «своеволии». Согласно «Мицукура кайфу: никки» один из священнослужителей пилой отрезал два куска дерева, площадью 1 сун в квадрате каждый. Нобунага сказал, что намерен оставить одну часть себе, другую передать императору $[17$, с. 256]. Вслед за этим он пожелал увидеть еще и благовонное дерево Ко:дзин (紅沈), также хранившееся в Сё:со:ин. Дерево доставили в замок Тамонъяма. Нобунага пожелал отрезать часть Ко:дзин, но отказался от своего намерения после того, как ему было сказано, что подобных примеров не было в прошлом. - См.: Тамонъин никки. Дайнихон сирё:, ч. 10, т. 21, с. 263 (на япон. яз.) на сайте www.hi.u-tokyo.ac.jp. После этого Нобунага самолично посетил хранилище и распорядился переместить сундук с Ко:дзин в то же место, где находилось дерево Рандзятай на том основании, что Ко:дзин - также «несравненное знаменитое благовоние Поднебесной» [17, с. 256, 257]. Император позднее пожаловал части Рандзятай бывшему кампаку Кудзё: Танэмити (1507-1594), придворному сановнику Кадзю:дзи Харухидэ (1523-1577) и даймё Мо:ри Тэрумото (1553-1625) [14, с. 134]. Похожим образом поступил Нобунага, «поделившийся» благовонным деревом с вассалами, в частности со знатоками чайной церемонии Сэн-но Рикю: и Цуда Со:гю:. - См.: Цуда Со:гю: Тяною никки. Дайнихон сирё:, ч. 10, т. 21, с. 267 (на япон. яз.) на сайте www.hi.u-tokyo.ac.jp.

31 Господин Хигасияма - сёгун Асикага Ёсимаса.

32 Буттэн (仏天) - Будды и божества-охранители буддийского закона.

${ }^{33}$ Сокровище - гомэйбуцу (御名物), дословно «знаменитая вещь». 


\section{нитое в трех странах ${ }^{34}$. Что может сравнится со славой и честью [его мило- сти] в нашем государстве ${ }^{35}$}

34 Трех странах - сангоку (三国), т. е. Индии, Китае и Японии.

35 События, связанные с отрезанием Нобунага части дерева Рандзятай, по-разному интерпретируются в исторической науке. Так, Окуно Такахиро полагал, что Нобунага был разгневан отказом императора 0:гимати отречься от престола и назначить «объединителя» Японии на должность сёгуна. Именно поэтому он оказал давление на императора и добился открытия сокровищницы Сё:со:ин (цит. по: [18, с. 221]). Иматани Акира трактовал происшедшее несколько иначе: с одной стороны Нобунага, прибыв в Нара с войском, напомнил о своей мощи храму Ко:фукудзи, обладавшему немалым влиянием в провинции Ямато, с другой - возвестил «старым силам» в столичной области Кинай о своих притязаниях на роль преемника сёгунов Асикага [19, c. 122, 123]. Вместе с тем Й. Ламерс не думал, что в данном случае Нобунага стремился кого-то запугать. Скорее он продемонстрировал как императору, так и своим вассалам и всей Японии, что стал «новым военным гегемоном в стране, наследником клана Асикага», при этом не занимая самого поста сёгуна [20, с. 120, 121, 123]. Канэко Хираку предложил ряд новых интерпретаций уже известных источников, относящихся к вышеуказанным событиям. Так, документ из «Исторических материалов великой Японии» (Дайнихон сирё:), который, согласно устоявшейся в науке трактовке, отражал гнев императора желанием Нобунага «взглянуть» на Рандзятай, на самом деле написан не государем, а, вероятно, сановником Сандзё:ниси Санэё. Более того, его содержание показывает не критику Нобунага, а скорее упреки, адресованные самому императору [21, с. 99-103]. Кроме того, Канэко подчеркнул, что Нобунага добился открытия государева хранилища при То:дайдзи, следуя установленным процедурам, и беспокоился о том, чтобы молва впоследствии не обвинила его в своеволии. Воины из отряда Нобунага вели себя в Нара дисциплинированно, не притесняя жителей Южной столицы. После посещения Сё:со:ин Нобунага наведался в Павильон Великого Будды в То:дайдзи, святилище Касуга и другие храмы,- тем самым, по мнению составителя «Тамонъин никки», проявив «учтивость» [18, с. 223]. Таким образом, он не стремился кого-то устрашить. Канэко думает, что Нобунага прибыл в Нара, чтобы показать он обладает силой для урегулирования запутанных политических противоречий в провинции Ямато, где существовали могущественные монастыри (Ко:фукудзи, То:дайдзи и др.), а также склонные к неподчинению магнаты (дом Мацунага). Отворение сокровищницы Сё:со:ин и срезание части благовонного дерева - символический шаг, целью которого было показать новые отношения между Нара и «объединителем Японии» [21, с. 96, 97]. Позицию Канэко поддержал Канда Тисато, отметивший, что поступок Нобунага не следует считать произволом или игнорированием авторитета «традиционных» центров власти. «Инцидент» с Рандзятай вообще не следует рассматривать в контексте отношений Нобунага с императорским двором, уверен историк [22, c. 66]. Похожей точки зрения придерживается и Кирино Сакудзин, считающий неправомерным говорить о давлении на императора. Напротив, для 0:гимати отрезание Нобунага части благовонного дерева ассоциировалось с возрождением императорского дома [23, с. 366]. Сакаи Арихиро по своим взглядам на данную проблему близок к Канэко: действия Нобунага должны были показать жителям Южной столицы, что он - новый ее властитель, сменивший Мацунага Хисахидэ. Вместе с тем Нобунага хотел, чтобы могущественные местные монастыри ощутили присутствие его власти в Нара [24, с. 171]. В то же время Кувата Тадатика рассматривал случай с Рандзятай в контексте увлечения Нобунага «знаменитыми вещами» (мэйбуцу) [25, с. 181]. Со своей стороны, Ямамуро Кё:ко не видит политического подтекста в действиях Нобунага, считая, что он желал заполучить редкую и ценную вещь [26, с. 60]. По-видимому, тяга Нобунага к шедеврам искусства, прежде всего предметам чайной церемонии, имела в данном случае первостепенное значение. Вместе с тем вполне возможно, что за этим неожиданным для многих его современников поступком скрывался и другой мотив. Нобунага не мог не знать об исключительности своих притязаний и о том, что Рандзятай хранится в сокровищнице императорской фамилии. Можно согласиться с Й. Ламерсом. Получив часть драгоценного древа, Нобунага продемонстрировал свое могущество. Об этом пишет и 0:та Гю:ити, автор хроники: его господин добился того, чего прежде не могли добиться многие сёгуны Асикага. Для Гю:ити и вассалов Нобунага это было проявлением его величия и славы. Заставив в столь короткие сроки согласиться со своим требованием и государя, и монастырь То:дайдзи, Нобунага показал силу своей власти, однако он не собирался запугивать императорский двор. 
4-я луна, 3-й день. Одзака явила свою вражду [к князю Нобунага]. Тотчас же [он] послал войско, [по его приказу] срезали весь урожай [на корню] и предали огню окрестности [Одзака] ${ }^{36}$.

(5). 4-я луна, 13-й день. Под покровом дождливой ночи Сасаки Дзё:тэй отступил из замка Исибэ у входа [в уезд] Ко:ка. [Князь Нобунага] немедленно разместил там войско Сакума Уэмон.

(6). 5-я луна, 5-й день. На празднестве Камо [были устроены] конные скачки ${ }^{37}$ - священнодействие и молитва о Поднебесной. По счастью, [князь Нобунага] был в столице, и посему [из святилища] почтительно просили: «Соизвольте распорядиться о конях». Нобунага соблаговолил выбрать двух коней - своего серого коня, на котором [он] часто скакал во время победоносных сражений, гнедого коня - и добавил восемнадцать резвых скакунов [своих] оумамавари. Общим счетом вышло двадцать лошадей, которых [он] приказал [поделить] на десять пар. Не говоря уже о конях, [князь Нобунага] приказал [предоставить для] каждого из них упряжь, [считавшуюся] знаменитым сокровищем, - седла, стремена, удила, [словом] все [необходимое], и [все] благоволил устроить превосходно и с великолепием. [Слуги] тонэри ${ }^{38}$, [которые вели коней], также были в прекрасных одеждах, о которых не слыхали и в древности. Затем десять жрецов в черных одеяниях и десять жрецов в красных одеяниях сели на этих двадцать коней. [Разделившись] по двое, [они] пускали вскачь коней, оспаривая победу [друг у друга]. Поскольку кони серой и гнедой [масти] были могучими, резвыми скакунами, и говорить нечего - оба коня [его милости] одержали победу. Рассказывать [об этом будут] и в грядущие времена, что и говорить, благородные и низко-

36 Хонгандзи в Одзака, главный центр «Истинной школы Чистой земли», не прерывал связей с сёгуном Асикага Ёсиаки, изгнанным Нобунага. В это время Икэда Кацумаса, Ко:дзай Этиго-но ками и другие союзники Хонгандзи развернули военные действия против Нобунага в провинции Сэтцу, захватив замок Накадзима и ряд крепостей. В провинции Кавати Юса Нобунори (?-1572), откликнувшись на призыв Хонгандзи, впустил в свой замок Такая силы Миёси Ясунага, еще одного врага Нобунага. Последний же не замедлил послать войско в Сэтцу и Кавати [10, с. 147-149].

37 Конные скачки - кэйба (競馬, курабэума, киойума). Устраивались в святилище Камигамо дзиндзя (Камо-вакэ-икадзути дзиндзя) в Киото в 5-й день 5-й луны, один из сезонных праздников (сэтинити 節日), отмечавшихся при императорском дворе и сопровождавшихся пиршеством (сэтиэ 節会). Упоминания о подобных конных состязаниях встречаются еще в хронике «Сёку Нихонги» («Продолжение Анналов Японии»). В 5-й день 5-й луны 701 г. за ними наблюдал император Момму (683-707) [27, с. 47]. Изначально скачки, а также конные состязания по стрельбе верхом, в которых участвовали воины столичных частей (эфу), проводились у дворца Бутокудэн. В 1093 г. при императоре Хорикава (1079-1107) кэйба были перенесены на территорию Камигамо дзиндзя. Скачки были священной церемонией, обращенной к божествам и призванной обеспечить в стране мир и хороший урожай [7].

38 Тонэри (舎人) - в эпоху Хэйан и позднее слуги, состоявшие на службе у знати, которые кормили и водили лошадей и быков. 
рожденные, молодые и старики толпами сбирались, [чтобы увидеть это зрелище]. Отдав распоряжения по разным делам Поднебесной, [в] 5-ю луну, 28-й день Нобунага отбыл в Гифу.

(7). 6-я луна, 5-й день. Дошли вести, что Такэда Сиро: Кацуёри ${ }^{39}$ напал и окружил замок Такатэндзин ${ }^{40}$, что был резиденцией Огасавара ${ }^{41}$, союзников [князя Нобунага] в провинции То:то:ми. Немедленно, чтобы напасть с тыла [на осаждавших],

[в] 6-ю луну, 14-й день, князь Нобунага с сыном выступили из Гифу в провинции Мино. В 17-й день прибыли [и встали] лагерем в замке Ёсида в Микава, владении Сакаи Саэмон-но дзё: ${ }^{42}$.

6-я луна, 19-й день. Когда князь Нобунага с сыном собирались переправляться через море на переправе Имагирэ, донесли, что Огасавара

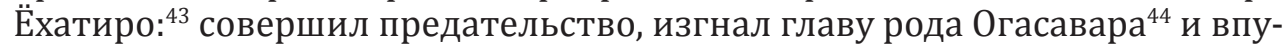

39 Такэда Кацуёри (1546-1582), сын и преемник даймё Такэда Сингэн (1521-1573). После смерти отца продолжил борьбу с Токугава Иэясу, который стремился отвоевать земли, перешедшие под власть дома Такэда в провинциях То:то:ми и Микава. В 1573 г. Иэясу вынудил капитулировать владетелей замка Нагасино в Микава, ранее перешедших на сторону дома Такэда. Посланные Кацуёри военачальники не сумели вовремя помочь осажденным. Порвав с Такэда, к Иэясу присоединились Окудайра Садаёси (1537-1598) и Нобумаса (1555-1615), хозяева замка Цукудэ в Микава. Кацуёри, отбиваясь от Иэясу, в то же время, в начале 1574 г., сам вторгся в восточные области провинции Мино, удел Ода Нобунага, где захватил замок Акэти и ряд крепостей. Во 2-й луне 1574 г. армия Иэясу подступила к замку Футамата в То:то:ми, контролируемому Такэда, после чего Кацуёри в 5 й луне выступил в поход [28, с. 87-89; 29, с. 99].

40 Такэда Кацуёри осадил замок Такатэндзин в провинции То:то:ми в 12-й день 5-й луны 1574 г., о чем известил в письме 0:и Такамаса, одного из своих вассалов [30, № 2295, с. 290].

41 Род Огасавара из То:то:ми в начале XVI в. признал сюзеренитет даймё Имагава Удзитика (1473-1526). В имена Огасавара Удзиоки и его сына Удзисукэ (Нобуоки, ?-1590), владетелей замка Такатэндзин, входит иероглиф удзи (氏), - даймё Имагава пожаловали им свой «фамильный» знак, составлявший часть их имен. В 1569 г., во время нападения армии Токугава Иэясу на То:то:ми, дом Огасавара отпал от Имагава Удзидзанэ (1538-1614), признал власть Иэясу и послал отряд, который участвовал в осаде замка Какэгава, где заперся Удзидзанэ. В 1570 г. Огасавара вместе с другими вассалами Токугава участвовали в битве при Анэгава, закончившейся поражением кланов Адзаи и Асакура от союзной армии Ода и Токугава. Огасавара неоднократно получали земельные пожалования от Токугава Иэясу [12, с. 163, 164].

42 Сакаи Тадацугу (1527-1596), вассал дома Токугава (Мацудайра), служивший еще Хиротада (1526-1549), отцу Токугава Иэясу. Женился на младшей сестре Хиротада. Был одним из приближенных Иэясу, когда тот был заложником в Сумпу, столице княжества Имагава. После отпадения Иэясу от дома Имагава стал одним из главнейших вассалов дома Токугава и владетелем замка Ёсида [15, с. 358].

43 Огасавара Удзисукэ (Огасавара Нобуоки, ?-1590), глава клана.

44 Глава рода - со:рё:. На деле в тот момент клан Огасавара возглавлял сам Удзисукэ. Не дождавшись помощи от Токугава Иэясу, он изгнал из замка своего дядю Огасавара Ёсиёри и его сторонников, противившихся передаче замка Такэда Кацуёри. Они перешли в близлежащий замок Мамусидзука во владениях дома Токугава. Удзисукэ же нарёкся Нобуоки, получив иероглиф нобу (信) - «фамильный» знак из имен даймё Такэда [31, с. 163]. 
стил [в замок] Такэда Сиро: [с войском] ${ }^{45}$. Делать нечего, [князь Нобунага с сыном, свернув] с пути, изволили возвратиться обратно в замок Ёсида. Иэясу также изволил прибыть в Ёсида из [замка] Хамамацу в провинции То:то:ми. Когда [Иэясу] приветствовал [князя Нобунага],

(8). [последний] был раздосадован тем, что на сей раз не смог вступить в битву. Взамен провианта ${ }^{46}$ [князь Нобунага] велел навьючить коня двумя кожаными мешками с золотом и преподнес в дар князю Иэясу ${ }^{47}$. [По приказанию князя Иэясу] тотчас же двое внесли один кожаный мешок в замок Сакаи Саэмон-но дзё:. И когда [князь Иэясу] соизволил взглянуть, [золота в мешке] было несметное [множество]. Благородные и низкорожденные, [вассалы] высокого и низкого положения из дома [Токугава] смотрели [на это], говоря, что и в старину про такое не слыхали, и каждый был изумлен. Сколь же велико могущество и величие [князя Нобунага], восхищались все. Трудно представить, что [было] на сердце князя Иэясу.

6-я луна, 21-й день. Нобунага с сыном вернулись из похода в Гифу в провинции Мино.

${ }^{45}$ Судя по всему, Огасавара Удзисукэ вскоре после начала осады Такатэндзин вступил в тайные переговоры с Такэда Кацуёри и выдвинул условия сдачи замка. В 23-й день 5-й луны Кацуёри в письме своему могущественному вассалу Анаяма Нобутада (1547-1582) сообщал, что согласился с этими условиями и послал клятвенные заверения Удзисукэ [30, № 2288, с. 287]. В 11-й день 6-й луны глава дома Такэда известил 0:и Такамаса о достигнутых успехах: захвачена цитадель То:ноо, в руках врага остался главный двор (хоммару) и второй двор (ниномару) замка. Он уверял адресата, что в течение трех дней замок будет захвачен [30, № 2295, с. 290]. Согласно «Военному зерцалу провинции Каи», Кацуёри пообещал пожаловать Удзисукэ земли в провинции Суруга с доходом в 10 тыс. кан мон [13, св. 19, с. 106]. Вскоре Огасавара Удзисукэ открыл ворота Такатэндзин. Интересно, что сохранилась копия грамоты с личной монограммой (као:) Такэда Кацуёри, согласно которой Огасавара Ёхатиро: (Удзисукэ) жаловались владения в Суруга в Симоката с доходом в 10 тыс. кан мон в обмен на владения в То:томи [30, № 2305, с. 293]. Захват этой стратегически важной твердыни, располагавшейся в центре То:то:ми, похоже, воодушевил Кацуёри. Ода Нобунага также был впечатлен успехом своего противника - в письме даймё Уэсуги Кэнсин он отметил, что «Сиро: хоть и молод, но чтит установления Сингэн, [он] может быть коварен, посему промашек быть не должно» [32, № 455, с. 755]. Так или иначе, взятие крепости Такатэндзин было лишь эпизодом в войне домов Такэда, с одной стороны, и Ода и Токугава - с другой.

46 Взамен провианта - гохё:ро:дай тоситэ (御兵粮代として).

47 Согласно «То:дайки», отбыв из замка Ёсида, Нобунага встретился с Иэясу, дал ему советы и в качестве помощи преподнес лошадь, груженую золотом, поскольку многие земли в провинции То:то:ми не возделывались. Сакаи Тадацугу, хозяин замка Ёсида, получил в дар от Нобунага превосходный короткий меч (вакидзаси), выкованный Садамунэ, знаменитым оружейником периода Намбокутё: из Камакура [9, с. 22]. 
(9). 7-я луна, 13-й день. Нобунага с сыном направили коней, чтобы покарать Каваути Нагасима ${ }^{48}$, в тот день расположились лагерем в Цусима. То, что зовется Каваути Нагасима в земле Овари - место, славящееся своей труднопроходимостью. [Там встречается] множество рек, вытекающих из провинции Мино. [Реки] Иватэгава, 0:такигава, Имасугава, Макитагава, Итиносэгава, Кундзэгава, Ямагутигава, Хидагава, Кисогава, водопад Ёро: и другие потоки из горных долин в конце концов сливаются, становясь широкими реками, многократно опоясывающими Нагасима с востока, севера и запада [на протяжении] 3-5 ри. С юга [плещется] бескрайнее море, что и говорить, с четырех сторон [это] место, к которому не подступиться. По этой причине злодеи и разбойники ${ }^{49}$ из соседних земель, собравшись, поселились [здесь] и почитали этот храм$^{50}$. Подвижничеством [через] памятование о Будде ${ }^{51}-$ исконным

48 В 1570 г. после призыва Кэннё, верховного настоятеля храма Хонгандзи, выступить против Нобунага приверженцы Икко:-икки из области Каваути (Каваути Нагасима) дельты, образованной нижним течением рек провинций Мино, Овари и Исэ, напали на замок Кокиэ на западе Овари, который оборонял Ода Нобуоки, младший брат Нобунага. Не устояв перед многочисленным противником, Нобуоки вынужден был покончить с собой [3, св. III, с. 154]. В 1571 г. Нобунага выступил с большой армией, по некоторым оценкам, превышавшей 50 тыс. человек, в поход на Каваути, но потерпел неудачу - его войско не смогло взять крепости Икко:-икки, защищенные естественной преградой речными водами. Во время отступления силы Нобунага понесли серьезные потери, погибли видные вассалы, в том числе Удзииэ Наомото из Мино [3, св. IV, с. 160]. В 1573 г. Нобунага выступил на север провинции Исэ, чтобы усмирить самураев, примкнувших к Нагасима Икко:-икки. Когда войско Нобунага двинулось обратно, оно было атаковано приверженцами Икко:-икки, которые устраивали засады и обстреливали врагов из луков и аркебуз. Большие потери понес арьергард армии, а его командир Хаяси Синдзиро: был убит [1, св. VI, с. 163, 164]. О:та Гю:ити в своей хронике отмечает «гнев» своего господина (гоупnун), вызванный «проступками» (катай 緩总) «злодеев» из Нагасима Каваути. Сам Нобунага в письме вассалу Кавадзири Хидэтака (1527-1582), датированному 23-м днем 7-й луны 4-го года Тэнсё:, сообщал о намерении полностью истребить (нэгири 根切) своих врагов, поскольку их вина (тога 各) не может быть прощена, и отказе принимать прошения о пощаде [32, № 460, с. 766].

49 Злодеи и разбойники - нэйдзин (位人), кё:то (凶徒). Нэйдзин (нэдзикэбито) - «коварный человек», «злодей» [33, с. 460].

50 Храм Гансё:дзи - центр «Истинной школы Чистой земли», подчинявшийся Хонгандзи в Одзака и руководивший действиями Икко:-икки в провинциях Исэ, Овари и Мино.

51 «Памятование о Будде»- величание Будды Амида - «Наму Амида буцу» («Слава Будде Амида»). Многократное произнесение этого славословия считалось главным видом подвижничества в «Школе Чистой земли» (Дзё:до:-сю), основанной наставником Хо:нэн (1133-1212). Именно оно вело к возрождению молящегося в Чистой земле [34, с. 423]. В то же время храм Хонгандзи, которому подчинялся храм Гансё:дзи - духовный центр Нагасима икко:-икки, относился к «Истинной школе Чистой земли» (Дзё:до: синсю), основоположником которой был Синран (1173-1262), ученик Хо:нэн. Согласно учению Синран нет нужды постоянно повторять «Наму Амида буцу». Если в душе человека пробудилась искренняя вера в Амида, он непременно возродится в Чистой земле [35, с. 206]. Даже однократное называние имени Амида «содержит в себе множество молений всех живых существ» [36, с. 127]. 
правилом [храма] Хонгандзи - пренебрегали. Из-за невежества в учении возгордились [своим] преуспеванием, дни проводили в буйных плясках $^{52}$ с утра до вечера. Предававшись делам мирским, построили в нескольких местах крепости ${ }^{53}$. [Они] с презрением относились к [властям] земли [Овари] и нарушали высочайшие законы ${ }^{54}$. И наказанных в земле [его милости ${ }^{55}$ укрывали в этом надежном убежище. Из-за того, что [они] захватывали владения [князя Нобунага] ${ }^{56}$, в один год господин Ода Хикосити ${ }^{57}$, младший брат князя Нобунага, пришел в селение Кокиэ в Каваути, возвел [там] крепость и [в ней] поселился. В прошлый год ${ }^{58}$ [во время] похода в Сига - в разгар противостояния князя Нобунага с Адзаи и Асакура, узнав, что [у князя Нобунага] скованы руки, осиным роем поднялись [силы] икки, непрестанно нападали и вынудили Ода Хикосити вспороть [свой] живот. Не перечесть [беззаконий, в которых они были] повинны. Уже давно питая [против них] гнев, Нобунага, из-за того, что распоряжался делами Поднебесной, был занят и соизволил отложить [их] наказание.

На сей раз [он] замыслил напасть со всех сторон и непременно изничтожить [мятежников $]^{59}$. С востока Ода Канкуро: ${ }^{60}$, старший сын [князя Нобунага], двигался через Итиэ.

52 Буйные пляски - рамбу (乱舞). Бином имеет ряд значений, в том числе: 1) неистовые танцы под музыку на пиру (танцующий мог при этом петь); 2) быстрый танец в представлении театра Но; 3) театр Но или же исполнение танца и декламирование нараспев отрывков из пьес Но. - См.: Нихон кокуго дайдзитэн. 2-е изд. Сёгакукан, 2001 (на япон. яз.) на сайте www.kotobank.co.jp.

53 Крепости - хадзё: (端城). Бином в период Сэнгоку также читался хадзиро. Синонимы - эдадзиро (枝城), дэдзиро (出城). Связанные с главным замком (нэдзиро 根城) форты, построенные в стратегически важных местах и защищающие подступы к нему $[33$, c. 476].

54 Высочайшие законы - гохатmо (法度).

55 Наказанных в земле [его милости] - окуни нитэ госэккан-но томогара (御国にて折 檻の輩). Окуни - провинция Овари. Госэккан (御折檻) - дословно «наказание [наложенное его милостью]». Сэккан - помимо известных значений «предостережение», «увещание», может значить «наказание» [33, с. 331].

56 Владения [князя Нобунага] - горё:ти ката (御領知方).

57 Ода Нобуоки (?-1570).

581570 г.

59 Общая численность армии, мобилизованной Нобунага для похода на Каваути Нагасима, могла составлять 70 тыс. человек [10, с. 131].

60 Ода Нобутада (1557-1582). 
Сопровождавшие [его милость Канкуро:] ${ }^{61}$ :

Ода Ко:дзукэ-но ками, Цуда Хандзаэмон, Цуда Матадзюро:, Цуда Итисукэ, Цуда Магодзю:ро:, Сайто: Синго, Янада Саэмонтаро:, Мори Сё:дзо:, Сакаи Эттю:-но ками, Икэда Сё:дзабуро:, Хасэгава Ёдзи, Ямада Сандзаэмон, Кадзивара Хэйдзи, Вада Синсукэ, Накадзима Бунго-но ками, Сэки Кодзю:ро:эмон, Сато: Рокудзаэмон, Итихаси Дэндзаэмон, Цукамото Кодайдзэн.

С запада через Катори [наступали]:

Сакума Уэмон, Сибата Сюри-но сукэ, Инаба Иё-но ками, [Инаба] Укё:но сукэ, Хатия Хё:го-но ками. Переправу Мацуноки защищали [силы] икки, но [воины князя Нобунага] разом переправившись через реку, на [своих] конях порубили многих [врагов].

Князь Нобунага [наступал] по главной дороге через Хаяо. Передовые силы [его милости]:

Киносита Коитиро:, Адзаи Симпати, Нива Горо:дзаэмон, Удзииэ Сакё:-но сукэ, Ига Ига-но ками, Иинума Кампэй, Фува Кавати, [Фува] Хикодзо:, Марумо Хё:го, [Марумо] Сабуро:бё:э, Сасса Кура-но сукэ, Итихаси Куро:дзаэмон, Маэда Матадзаэмон, Тю:дзё: Сё:гэн, Кавадзири Ёхё:э, Цуда 0:суми-но ками, Ииноо Оки-но ками.

[Силы] икки преградили [путь] в деревне Кокиэ. [Князь Нобунага], выбив [их оттуда], проследовал [дальше]. Так же подошли [отряды] икки из Синохасэ, и преградили [путь]. Тотчас же Киносита Коитиро: и Адзаи Симпати устремились [на них]. Переплыв на кораблях устье [реки] Кодамисакигава, [воины] икки поднялись на дамбу и держали [там] оборону. [Туда] устремился Нива Горо:дзаэмон, разбил и сразил многих [врагов], дотла сжег Маэгасу, Эбиэдзима, Каро:тодзима, Икуирадзима.

В тот день Нобунага соблаговолил разбить полевой лагерь в Гомё:.

В 15-й день Куки Ума-но дзё: [приготовил корабль] атакэ бунэ ${ }^{62}$, Такигава Сакон, Ито: Сан-но дзё:, Мидзуно Каммоцу - также атакэ бунэ, Симада Токоро-но сукэ и Хаяси Садо-но ками приготовили [корабли]

${ }^{61}$ Сопровождавшие [его милость Канкуро:] - отомосю (御伴衆). В английском переводе - "his life guards" [11, p. 210]. Однако речь идет не о телохранителях, а о подчиненных Ода Нобутада командирах военных отрядов, среди которых были его близкие родственники: Ода Нобуканэ (Ода Ко:дзукэ-но ками, 1543-1614), Ода Хидэнари (Цуда Хандзаэмон, ?-1574), Ода Нагатоси (Цуда Матадзюро:, ?-1582) и др.

${ }^{62}$ Атакэ бунэ (安宅船) - крупные военные корабли периода Сэнгоку водоизмещением до 300 тонн и длиной до 30-40 м, верхняя часть которых укреплялась толстыми деревянными досками с бойницами для обстрела противника из луков и огнестрельного оружия. Могли иметь на палубе двух-, трехэтажные башни (ягура) [7]. 
какои бунэ ${ }^{63}$. Помимо того, собрали судна из разных гаваней: Каниэ, Арако, Ацута, О:дака, Кита, Тэрамото, 0:но, Токонабэ, Нома, Уцуми, Кувана, Сирако, Хирао, Такамацу, Аноноцу, Кусу, Хосокуми. Управитель земли [Исэ] князь Отясэн ${ }^{64}$, ведя за собой военачальников ${ }^{65}$ из Таруми, Торияноо, О:хигаси, Коцукури, Тамару, Саканаи, взошел на большой корабль и явился [на место сражения]. Воины всех отрядов подняли на кораблях стяги, [каждый отряд] - свои, и подобно [бесчисленным] сверкающим звездам, облакам и туману с четырех сторон устремились к Нагасима, в миг подступили ко всем проходам и атаковали. [Приверженцы] икки были разгромлены и, взяв с собой жен и детей, бежали в Нагасима.

Нобунага с сыном, перебравшись в Тономё:, изволил расположить [свою] ставку в усадьбе Ито: поблизости от [врага]. [Князь Нобунага] объехал верхом и окинул взором [окрестности], приказал занять позиции у всех проходов. Враги укрепились в пяти замках - Синохасэ, 0:дории, Янагасима, Накаэ, Нагасима.

Отряды, штурмовавшие Синохасэ:

Цуда О:суми-но ками, Цуда Итисукэ, Цуда Магодзю:ро:, Удзииэ Сакё:но сукэ, Ига Ига-но ками, Иинума Кампэй, Адзаи Симпати, Мидзуно Симоцукэ-но ками, Ёкои Ута-но сукэ.

Отряды, штурмовавшие 0:дории:

Сибата Сюри-но сукэ, Инаба Иё-но ками, [Инаба] Хикороку, Хатия Хё:го-но ками.

[Они] встали лагерем в Имадзима, [одновременно] по реке подплыли большие корабли и напали [на врага].

К силам [во главе с] Сакума и его сыном, сдерживавшим [врага], были присоединены люди провинции 0:ми, [они] расположились лагерем в деревне Сакатэ.

Отряды, расположившиеся лагерем в деревне Осицукэ к востоку от Нагасима:

Итихаси Куро:эмон, Фува Хикодзо:, Нива Горо:дзаэмон.

Отряды, нападавшие через Каро:тодзима:

Ода Симоцукэ-но ками, Хаяси Садо-но ками, Симада Токоро-но сукэ.

Помимо того, приплыли несколько сотен судов из провинции Овари, не [оставив свободного] места на море.

${ }^{63}$ Какои бунэ - собирательное название для военных судов периода Сэнгоку, верхняя часть которых защищалась толстыми деревянными досками или металлическими пластинами. К ним относились корабли атакэ бунэ, сэки бунэ и др. В данном случае, вероятно, имеются в виду корабли меньшие по размеру, чем атакэ бунэ.

64 Ода Нобукацу (1558-1630), второй по старшинству сын Нобунага.

65 Военачальники - муся дайсё: (武者大将). 
Отряды, нападавшие с юга через 0:дзима:

Гохондзё, Камбэ Сансити, люди [из] Кувана.

Кроме того, приплыли несколько сотен судов и больших кораблей из провинции Исэ, не [оставив свободного] места на море. Когда все [эти] отряды приблизились к О:дории и Синохасэ и напали, разрушая стены и башни выстрелами из больших аркебуз, в обоих замках [защитников] охватило смятение. [Они] умоляли [князя Нобунага] о пощаде, но [его милость объявил], что это никак невозможно, намереваясь в назидание [другим] злодеям заморить [их] голодом и утолить свой гнев, [порожденный их] давними проступками и бесчинствами, и не внял [их просьбам] ${ }^{66}$. В это время,

[в] 8-ю луну, 2-й день, ночью [разразилась] необычайно сильная буря. Когда под ее прикрытием сброд, осажденный в замке О:дории, посреди ночи выбрался и [стал] разбегаться, [воины князя Нобунага] зарубили примерно тысячу мужчин и женщин ${ }^{67}$.

8-я луна, 12-й день. Осажденные в замке Синохасэ, повиновавшись, твердо [поклялись], что в [крепости] главного настоятеля ${ }^{68}$ Нагасима преданно послужат [князю Нобунага], и потому [он] сохранил им жизнь, и прогнал в Нагасима ${ }^{69}$.

(10). Меж тем [князь Нобунага ранее] построил крепость на перевале Киномэ, разместив [там] Хигути ${ }^{70}$, но [кто знает], какие же обиды таил [он в сердце]? Когда [Хигути], оставив крепость и взяв с собой

${ }^{66}$ Нобунага в письме вассалу Акэти Мицухидэ, посланном в 29-й день 7-й луны, сообщал, что его войско обложило О:дории и Синохасэ, по слухам, в обоих крепостях совсем нет провианта, и они не продержатся больше 3-5 дней [32, № 463, с. 769].

67 Нобунага писал Кавадзири Хидэтака (7-й день 8-й луны), что приказал «вырезать» (надэгири 撫切) «женщин и мужчин», а до падения Гансё:дзи (крепости Нагасима) осталось недолго. Он также «твердо» отверг просьбы о снисхождении, намереваясь «истребить» защитников [32, № 467, с. 775].

68 Главный настоятель - хонбо:дзу (坊主).

69 В «Записях о Нобунага» (список дома Икэда) указывается, что переговоры с гарнизоном Синохасэ завершились успехом благодаря Гохондзё (御本所) - которым, по предположению составителей «Дайнихон сирё:», был Ода Нобукацу (он же Китабатакэ Томотоё), сын Нобунага. - См.: Синтё:ки. Икэда-кэ бунко бон. Дайнихон сирё:, ч. 10, т. 24, с. 22 (на япон. яз.) на сайте www.hi.u-tokyo.ac.jp. Историк Кинрю: Сидзука отмечает, что в Нагасима узнали о предательстве защитников Синохасэ и не впустили их. После этого последние пытались бежать, но были уничтожены войсками Нобунага [37, с. 283].

70 Хигути Наофуса (?-1574), самурай из уезда Саката провинции О:ми, вассал рода Хори. Первоначально, как и Хори, подчинялся дому Адзаи. В 1570 г. примкнул к Нобунага [38, c. 381]. 
жену и детей, бежал в [уезд] Ко:ка, Хасиба Тикудзэн-но ками послал за ним погоню, на полпути [их схватил и] казнил. Головы мужа и жены [по приказанию Хасиба] были доставлены в ставку [князя Нобунага в] Нагасима.

На сей раз не готовые к долгой кампании в Нагасима в 7-ю луну, 13-й день, в великой спешке мужчины и женщины, благородные и низкорожденные, с [разных] островов в бессчетном множестве бежали в три места - Нагасима, Янагасима и Накаэ. Вот уже 3 месяца [защитники] держали [оборону], больше половины [из них] умерли от голода ${ }^{71}$.

9-я луна, 29-й день. [Приверженцы иккu], умоляя [князя Нобунага о снисхождении], оставили Нагасима. Когда [они] садились на многочисленные корабли, [по ним] разом выстрелили [из всех] аркебуз, без счета было зарублено, [а тела брошены] в реку. Среди них храбрецы [числом] примерно семь-восемь сотен, [раздевшись] догола, лишь с обнаженными мечами [в руках] бросились в бой и вырвались [из окружения], [отпрыски] высочайшего рода [Ода] ${ }^{72}$ и многие именитые [вассалы] полегли в бою [с ними]. Устремившись в небольшой проход [в рядах войска дома Ода], [они] ворвались в хижины, оставшиеся без присмотра ${ }^{73}$, и оделись по своему усмотрению. После этого, переправившись через реку и рассеявшись, отошли к [горе] Тагияма, на север Исэ, [и] бежали в Одзака. Замки Накаэ и Янагасима, - в обоих замках оставалось примерно 20 тыс. мужчин и женщин, - [по приказу князя Нобунага] не единожды обнесли оградой, обложив [кругом]. [Его милость] приказал с четырех сторон

71 В вышеупомянутом послании Нобунага извещал Акэти Мицухидэ о том, что в Нагасима сбежалось множество простолюдинов (дзо:нин 䧱人), и, по слухам, в этой крепости от голода уже погибло много «мужчин и женщин» [32, № 463, с. 769].

72 Согласно «То:дайки», погибло больше десяти родичей Нобунага [9, с. 23]. Вада Ясухиро, суммируя данные из разных источников, повторяет эту цифру. В частности пали в бою Ода Нобухиро (?-1574), единокровный брат Нобунага; Ода Хидэнари (?-1574), его младший брат; Ода Нобунари (?-1574), Ода Нобумаса (?-1574) и Ода Сэн (?-1574), его двоюродные братья; Ода Нобунао (1546-1574); Ода Нобуцугу (?-1574), его дядя; Ода Кю:сабуро: и др. [39, с. 69].

73 Хижины, оставшиеся без присмотра, - русу-но коя коя (留守のこや々). В списке дома Икэда в аналогичном фрагменте читаем вместо русу-но коя коя читаем гохондзин-но коя коя (御本陣小屋々), что дословно значит «хижины главного лагеря его милости». - См.: Синтё:ки. Икэда-кэ бунко бон. Дайнихон сирё:, ч. 10, т. 24, с. 329 (на япон. яз.) на сайте www.hi.u-tokyo.ac.jp. Речь идет о временных постройках («бараках») в лагере Нобунага, где размещались воины его армии во время военной кампании против Нагасима Икко:-икки. 
пустить огонь и сжечь заживо [защитников $]^{74}$. Исполнив задуманное, в 24-й день 9-й луны [князь Нобунага] вернулся из похода в Гифу.

\section{Аитература}

1. Ивасава Ёсихико, Окуно Такахиро (комм.). Синтё:-ко: ки. 9-е изд. Токио: Кадокава сётэн; 1996. (На япон. яз.)

2. Полхов С. А. (пер. и комм.). О:та Гю:ити. «Записи о князе Нобунага». Свитки I, II. Вестник Института востоковедения РАН. 2019;(4):148-168.

3. Полхов С. А. (пер. и комм.). О:та Гю:ити. «Записи о князе Нобунага». Свитки III, IV. В: Горяева Л. В., Настич В. Н. (отв. ред.). Труды Института востоковедения РАН. Вып. 28. Т. III. М.: ИВ РАН; 2020. С. 123-170.

4. Полхов С. А. (пер. и комм.).О:та Гю:ити. «Записи о князе Нобунага». Свиток V. Ориенталистика. 2020;3(1):31-48. DOI: 10.31696/2618-7043-2020-3-1-31-48.

5. Полхов С. А. (пер. и комм.). О:та Гю:ити. «Записи о князе Нобунага». Свиток VI. (Часть I). Вестник Института востоковедения РАН. 2020;(1):236-239. DOI: $10.31696 / 2618-7302-2020-1-226-239$.

74 Исследователи по-разному объясняют жестокость, с которой Нобунага расправился с Нагасима Икко:-икки. Согласно одной точке зрения, «набирающая силу власть» Нобунага подавляла с помощью насилия развитие самоуправляющихся социальных и экономических центров «Истинной школы Чистой земли» (дзинай) в области То:кайдо:, что не могло не вызвать широкого недовольства. В этой обстановке в 1570 г. верховный настоятель Одзака Хонгандзи призвал к вооруженному сопротивлению Нобунага. Ожесточенность борьбы между Нагасима Икко:-икки и Нобунага, в которой были убиты и его близкие родственники, связана с высокой концентрацией военной силы [37, с. 294, 295]. Со своей стороны Канда Тисато считает, что жестокое истребление последователей Икко:-икки, включая женщин и детей, укрывшихся в крепостях области Каваути, отражает стремление Нобунага «опозорить» (дискредитировать) храм Гансё:дзи и Икко:-икки в глазах «народа». В период Сэнгоку «народ», чтобы выжить, вставал на сторону того властителя, который лучше других справлялся с «кризисными» ситуациями, и покидал того, кому это не удавалось. Таким образом, эта «резня» была «политическим воззванием» Нобунага, целью которого было отдалить «народ» от Икко:-икки [40, с. 130]. Мнение Канда не кажется вполне обоснованным. О:та Гю:ити неоднократно пишет о ненависти Нобунага к жителям Нагасима Каваути, вызванной их многочисленными «проступками» и «бесчинствами». После самоубийства младшего брата и провала двух крупных военных кампаний, сопровождавшегося гибелью видных вассалов, Нобунага, по-видимому, стал рассматривать войну против Нагасима Икко:-икки как личную вендетту. В «То:дайки» убийство сдавшихся и покидавших Нагасима на кораблях защитников объясняется «злобой» (икон 遺恨) Нобунага из-за смерти брата и «именитых» самураев дома Ода [9, с. 22]. Таким образом, причины беспощадной расправы с обитателями Каваути Нагасима - желание Нобунага отомстить за прошлые неудачи и уничтожить сильного противника, способного к продолжению сопротивления. Если и можно видеть в этом событии «воззвание», то оно скорее было адресовано всем недругам Нобунага, а не только «народу». В уезде Ясу провинции 0:ми противостояние между Нобунага и приверженцами Икко:-икки было куда менее масштабным и кровопролитным, чем в Каваути. Жители укрепленных поселений Канагамори и Миякэ в уезде Ясу этой провинции, примкнувшие к Икко:-икки, в 1571 г. вынуждены были сдаться. В 1572 г. они вновь восстали, но довольно быстро сдались, выдали заложников и были помилованы (подробнее см.: [41, с. 59-62]). Следовательно, Нобунага мог сравнительно мягко обойтись с участниками Икко:-икки. 
6. Полхов С. А. О:та Гю:ити и его «Записи о князе Нобунага»: некоторые итоги изучения в японской исторической науке. Вестник Института востоковедения РАН. 2019;(3):115-133. Available at: https://www.ivran.ru/f/«Vestnik_ Instituta_vostokovedeniya_RAN»_2019_№3.pdf.

7. Като: Сюити (ред.). Сэкай дайхякка дзитэн. Хэйбонся; 2007. (На япон. яз.)

8. Касахара Кадзуо, Иноуэ Тосио (сост. и комм.). Асакура симацуки. Рэннё. Икко: икки. Нихон сисо: тайкэй. Токио: Иванами сётэн; 1972. Т. 17. (На япон. яз.)

9. То:дайки. Сисэки дзассан. Токио: Яги сётэн; 1995. Т. 2. (На япон. яз.).

10. Танигути Кацухиро. Ода Нобунага кассэн дзэнроку. Токио: Тю:о: ко:рон синся; 2002. (На япон. яз.)

11. Elisonas J. S. A., Lamers J. P. (transl. and ed.). The Chronicle of Lord Nobunaga by Ōta Gyūichi. Boston, Leiden: Brill; 2011.

12. Сибацудзи Сюнроку, Хираяма Ю:, Курода Мотоки, Марусима Кадзухиро (сост.). Такэда-си касиндан дзиммэй дзитэн. Токио: То:кё:до: сюппан; 2015. (На япон. яз.)

13. Сакаи Кэндзи (исслед., комм.). Коё: гункан тайсэй. Токио: Кю:ко сёин; 1994. Т. 2. (На япон. яз.)

14. Вада Ясухиро. Синтё:-ко: ки. Сэнгоку хася-но иккю: сирё:. Токио: Тю:о: ко:рон синся; 2018. (На япон. яз.)

15. Абэ Такэси, Нисимура Кэйко (ред.). Сэнгоку дзиммэй дзитэн. Компакуто хан. Токио: Син дзинбуцу о:райся; 2006. (На япон. яз.)

16. Сато: Синъити. Комондзёгаку ню:мон. Токио: Хо:сэй дайгаку сюппанкёку; 2003. (На япон. яз.)

17. Канэко Хираку. Мицукура кайфу: никки. Ода Нобунага кэнрёку рон. Токио: Ёсикава ко:бункан; 2015. (На япон. яз.)

18. Канэко Хираку. Ода Нобунага кэнрёку рон. Токио: Ёсикава ко:бункан; 2015. (На япон. яз.)

19. Иматани Акира. Нобунага то тэнно: Токио: Ко:данся; 2002. (На япон. яз.)

20. Ламерс Й. П. Японский тиран. Новый взгляд на японского полководца Ода Нобунага. СПб.: Евразия; 2012.

21. Канэко Хираку. Ода Нобунага. Тэнкабито-но дзицудзо: Токио: Ко:данся; 2014. (На япон. яз.)

22. Канда Тисато. Ода Нобунага. Токио: Тикума синсё; 2014. (На япон. яз.)

23. Кирино Сакудзин. Ода Нобунага. Токио: Синдзинбуцу о:райся; 2011. (На япон. яз.)

24. Сакаи Арихиро. Нобунага ва надзэ Рандзятай о киритотта но ка. В: Ватанабэ Даймон (ред.). Нобунага кэнкю:-но сайдзэнсэн 2. Токио: Ё:сэнся; 2017. С. 157-172. (На япон. яз.)

25. Кувата Тадатика. Ода Нобунага. Токио: Кадокава сётэн; 1964. (На япон. яз.)

26. Ямамуро Кё:ко. О:гон тайко:. Токио: Тю:о: ко:ронся; 1992. (На япон. яз.)

27. Мещеряков А. Н. (пер. и комм.). Сёку Нихонги. Св. II. В: Мещеряков А. Н. (ред.). История и культура традищионной Японии. М.: РГГУ; 2011. Т. 2. С. 39-69.

28. Сибацудзи Сюнроку. Такэда Кацуёри. Токио: Синдзинбуцу о:райся; 2003. (На япон. яз.) 
29. Хонда Такасигэ. Тэйхон. Токугава Иэясу. Токио: Ёсикава ко:бункан; 2010. (На япон. яз.)

30. Сибацудзи Сюнроку, Курода Мотоки (сост.). Сэнгоку ибун. Такэда-си хэн. Токио: То:кё:до: сюппан; 2003. Т. 3. (На япон. яз.)

31. Марусима Кадзухиро. Такэда Каиуёри. Тамэсарэру сэнгоку даймё:-но кирё: Токио: Хэйбонся; 2017. (На япон. яз.)

32. Окуно Такахиро (сост. и комм.). Дзо:тэй Ода Нобунга мондзё-но кэнкю: Токио: Ёсикава ко:бункан; 1988. Т. 1. (На япон. яз.)

33. Судзуки Масандо (сост.). Сэнгоку комондзё ё:го дзитэн. Токио: То:кё: сюппандо:; 2019. (На япон. яз.)

34. Трубникова Н. Н., Бачурин А. С. История религий Японии IX-XII вв. М.: Наталис; 2009.

35. Григорьева Т. П. (отв. ред.). Буддизм в Японии. М.: Восточная литература; 1993.

36. Трубникова Н. Н., Бабкова М. В. Обновление традиций в японской религиозно-философской мысли XIII-XIV вв. М.: Росспэн; 2014.

37. Кинрю: Сидзука. Икко:-икки рон. Токио: Ёсикава Ко:бункан; 2004.

38. Танигути Кацухиро. Ода Нобунага касин дзиммэй дзитэн. 2-е изд. Токио: Ёсикава ко:бункан; 2010. (На япон. яз.)

39. Вада Ясухиро. Ода Нобутада. Тэнкабито-но тякунан. Токио: Тю:о: ко:рон синся; 2019. (На япон. яз.)

40. Канда Тисато. Нобунага то Исияма кассэн. 2-е изд. Токио: Ёсикава ко:бункан; 2008. (На япон. яз.)

41. Мацусита Хироси. Ода Нобунага. Соно кёдзо: то дзицудзо: Токио: Санрайдзу сюппан; 2014. (На япон. яз.)

\section{References}

1. Ōta Gyūichi. Iwasawa Yoshihiko, Okuno Takahiro (ed.). Shinchō-kō ki. $9^{\text {th }}$ ed. Tokyo: Kadokawa shoten; 1996. (In Japan.)

2. Polkhov S. A. (transl. and comm.). Ōta Gyūichi. "Shinchō-kō ki". Books I, II. Vestnik Instituta vostokovedeniya RAN = Journal of the Oriental Studies Institute RAS. 2019;(4):148-168. (In Russ.)

3. Polkhov S. A. (transl. and comm.). Ōta Gyūichi. Shinchō-kō ki. Books III, IV. In: Goryaeva L. V., Nastich V. N. (ed.). Papers of the Institute of Oriental Studies of the RAS. Issue 28. Vol. III. Moscow, 2020, pp. 123-170. (In Russ.)

4. Polkhov S. A. (transl. and comm.). Ōta Gyūichi. "Shinchō-kō ki". Book V. Orientalistica. 2020;3(1):31-48. (In Russ.) DOI: 10.31696/2618-7043-2020-3-1-31-48.

5. Polkhov S. A. (transl. and comm.). Ōta Gyūichi. "Shinchō-kō ki”. Book VI (Part I). Vestnik Instituta vostokovedeniya RAN = Journal of the Oriental Studies Institute RAS. 2020;(1):226-239. (In Russ.) DOI: 10.31696/2618-7302-2020-1-226-239.

6. Polkhov S. A. Ōta Gyūichi and his "Shinchō-kō ki": Some Results of Studying in Japanese Historical Science. Vestnik Instituta vostokovedeniya RAN = Journal of the Oriental Studies Institute RAS. 2019;(3):115-133. (In Russ.) Available at: https:// www.ivran.ru/f/«Vestnik_Instituta_vostokovedeniya_RAN»_2019_№3.pdf. 
7. Katō Shūichi (ed.). Sekai daihyakka jiten. Heibonsha; 2007. (In Japan.)

8. Kasahara Kazuo, Inoue Toshio (ed.). Asakura Shimatsuki. Rennyo, Ikkō-ikki. Nihon shisō taikei. Tokyo: Iwanami shoten; 1972. Vol. 17. (In Japan.)

9. Tōdaiki. Shiseki zassan. Tokyo: Yagi shoten; 1995. Vol. 2. (In Japan.)

10. Taniguchi Katsuhiro. Oda Nobunaga kassen zenroku. Tokyo: Chūō kōron shinsha; 2002. (In Japan.)

11. Elisonas J. S. A., Lamers J. P. (transl. and ed.). The Chronicle of Lord Nobunaga by Ōta Gyūichi. Boston, Leiden: Brill; 2011.

12. Shibatsuji Shunroku, Hirayama Yū, Kuroda Motoki, Marushima Kazuhiro (ed.). Takeda-shi kashindan jimmei jiten. Tokyo: Tōkyōdō shuppan; 2015. (In Japan.)

13. Sakai Kenji (ed.). Koyō Gunkan Taisei. Tokyo: Kyūko shoin; 1994. Vol. 2. (In Japan.)

14. Wada Yasuhiro. Shinchō-kō ki. Sengoku hasha-no ikkyū shiryō. Tokyo: Chūō kōron shinsha; 2018. (In Japan.)

15. Abe Takeshi, Nishimura Keiko (ed.). Sengoku jimmei jiten. Konpakuto han. Tokyo: Shinjinbutsu ōraisha; 2006. (In Japan.)

16. Satō Sin'ichi. Komonjogaku nyūmon. Tokyo: Hōsei daigaku shuppankyoku; 2003. (In Japan.)

17. Kaneko Hiraku. Mitsukura kaifū nikki. Oda Nobunaga kenryoku ron. Tokyo: Yoshikawa kōbunkan; 2015, pp. 253-258.

18. Kaneko Hiraku. Oda Nobunaga kenryoku ron. Tokyo: Yoshikawa kōbunkan; 2015. (In Japan.)

19. Imatani Akira. Nobunaga to tennō. Tokyo: Kōdansha; 2002. (In Japan.)

20. Lamers J. P. Japonius Tyrannus. The Japanese Warlord Oda Nobunaga Reconsidered. St Petersburg: Evraziya; 2012. (In Russ.)

21. Kaneko Hiraku. Oda Nobunaga. Tenkabito-no jitsuzō. Tokyo: Kōdansha; 2014. (In Japan.)

22. Kanda Chisato. Oda Nobunaga. Tokyo: Chikuma shinsho; 2014. (In Japan.)

23. Kirino Sakujin. Oda Nobunaga. Tokyo: Shinjinbutsu ōraisha; 2011. (In Japan.)

24. Sakai Arihiro. Nobunaga wa naze Ranjatai o kiritotta ka. In: Watanabe Daimon (ed.). Nobunaga kenkyū-no saizensen 2. Tokyo: Yōsensha; 2017, pp. 157-172. (In Japan.)

25. Kuwata Tadachika. Oda Nobunaga. Tokyo: Kadokawa shoten; 1964. (In Japan.)

26. Yamamuro Kyōko. Ōgon taikō. Tokyo: Chūō kōrōn shinsha; 1992. (In Japan.)

27. Meshcheryakov A. N. (transl. and comm.). Shoku Nihongi. Book II. In: Meshcheryakov (ed.). The History and Culture of the Traditional Japan. Moscow: RGGU; 2011, pp. 39-69. (In Russ.)

28. Shibatsuji Shunroku. Takeda Katsuyori. Tokyo: Shinjinbutsu ōraisha; 2003. (In Japan.)

29. Honda Takashige. Teihon. Tokugawa Ieyasu. Tokyo: Yoshikawa kōbunkan; 2010. (In Japan.)

30. Shibatsuji Shunroku, Kuroda Motoki (ed.). Sengoku ibun. Takeda-shi hen 3. Tokyo: Tōkyōdō shuppan; 2003. (In Japan.)

31. Marushima Kazuhiro. Takeda Katsuyori. Tamesareru sengoku daimyō-no kiryō. Tokyo: Heibonsha; 2017. (In Japan.) 
32. Okuno Takahiro (ed.). Zōtei Oda Nobunaga monjo-no kenkyū. Tokyo: Yoshikawa kōbunkan; 1988. Vol. 1. (In Japan.)

33. Suzuki Masando (ed.). Sengoku komonjo yōgo jiten. Tokyo: Tōkyōdō shuppan; 2019. (In Japan.)

34. Trubnikova N. N., Bachurin A. S. The History of the Religions of Japan: IX-XII Centuries. Moscow: Natalis; 2009. (In Russ.)

35. Grigorieva T. P. (ed.). Buddhism in Japan. Moscow: Vostochnaya literatura; 1993. (In Russ.)

36. Trubnikova N. N., Babkova M. V. The renewal of Traditions in Japanese Religious and Philosophical Thought in XIII-XIV Centuries. Moscow: Rosspen; 2014. (In Russ.)

37. Kinryū Shizuka. Ikkō-ikki ron. Tokyo: Yoshikawa kōbunkan; 2004. (In Japan.).

38. Taniguchi Katsuhiro. Oda Nobunaga kashin jimmei jiten. $2^{\text {nd }}$ ed. Tokyo: Yoshikawa kōbunkan; 2010. (In Japan.)

39. Wada Yasuhiro. Oda Nobutada. Tenkabito-no chakunan. Tokyo: Chūō kōrōn shinsha; 2019. (In Japan.)

40. Kanda Chisato. Nobunaga to Ishiyama kassen. $2^{\text {nd }}$ ed. Tokyo: Yoshikawa kōbunkan; 2008. (In Japan.)

41. Matsushita Hiroshi. Oda Nobunaga. Sono kyōzō to jitsuzō. Tokyo: Sanraizu shuppan; 2014. (In Japan.)

Информация о переводчике

Полхов Святослав Александрович, кандидат исторических наук, старший научный сотрудник Центра японских исследований Института востоковедения РАН, г. Москва, Российская Федерация.

\section{Раскрытие информации о конфликте интересов}

Автор заявляет об отсутствии конфликта интересов.

\section{Информация о статье}

Поступила в редакцию: 6 апреля 2020 г. Одобрена рецензентами: 16 апреля 2020 г. Принята к публикации: 19 апреля 2020 г.

\section{Information about the translator}

Svyatoslav A. Polkhov, Ph. D. (Hist.), Senior Research Fellow, Center for Japanese Studies, Institute of Oriental Studies of the Russian Academy of Sciences, Moscow, Russian Federation.

\section{Conflicts of Interest Disclosure}

The author declares that there is no conflict of interest. 